PNNL - 23000

\title{
Cost-Effectiveness of ASHRAE Standard 90.1-2010 for the State of Utah
}

$\begin{array}{lll}\text { R Hart } & \text { J Zhang } & \text { SA Loper } \\ \text { MI Rosenberg } & \text { EE Richman } & \text { M Myer } \\ \text { Y Xie } & \text { DB Elliott } & \end{array}$

November 2013

Pacific Northwest

NATIONAL LABORATORY

Proudly Operated by Battelle Since 1965 


\title{
DISCLAIMER
}

This report was prepared as an account of work sponsored by an agency of the United States Government. Neither the United States Government nor any agency thereof, nor Battelle Memorial Institute, nor any of their employees, makes any warranty, express or implied, or assumes any legal liability or responsibility for the accuracy, completeness, or usefulness of any information, apparatus, product, or process disclosed, or represents that its use would not infringe privately owned rights. Reference herein to any specific commercial product, process, or service by trade name, trademark, manufacturer, or otherwise does not necessarily constitute or imply its endorsement, recommendation, or favoring by the United States Government or any agency thereof, or Battelle Memorial Institute. The views and opinions of authors expressed herein do not necessarily state or rellect those of the United States Government or any agency thereof

\author{
PACIFIC NORTHWEST NATIONAL LABORATORY \\ operated by \\ BATTELLE \\ for the \\ UNITED STATES DEPARTMENT OF ENERGY \\ under Contract DE-AC05-76RL01830 \\ Printed in the United States of America \\ Available to DOE and DOE contractors from the \\ Office of Scientific and Technical Information, \\ P.O. Box 62, Oak Ridge, TN 37831-0062; \\ ph: (865) 576-8401 \\ fax: $(865) 576-5728$ \\ email: reports@adonis.osti.gov \\ Available to the public from the National Technical Information Service, \\ U.S. Department of Commerce, 5285 Port Royal Rd.., Springfield, VA 22161 \\ ph: (800) 553-6847 \\ fax: (703) 605-6900 \\ email: orders@ntis.fedworld.gov \\ online ordering: http://www.ntis.gov/ordering.htm
}

This document was printed on recycled paper.

(9/2003) 


\section{ASHRAE Standard 90.1-2010 Provides Cost-Effective Savings for Commercial Buildings in the State of Utah}

Moving to the ANSI/ASHRAE/IES Standard 90.1-2010 version from the Base Code (90.1-2007) is costeffective for all building types and climate zones in the State of Utah.

Table 1 shows the statewide economic impact of upgrading to 90.1-2010 in terms of the annual energy cost savings in dollars per square foot, the additional cost per square foot required by the upgrade, and the simple payback period in years. Average values are weighted averages for all building types considered in all climate zones in the state, based on weightings shown in Table 6 .

Table 1. Utah Average Savings and Cost Weighted by Climate Zone and Building Type Weighted Cost Savings and Added Cost per Square Foot

Annual Cost Savings, $\$ / \mathrm{ft}^{2}$

Added Construction Cost, $\$ / \mathrm{ft}^{2}$

State of Utah Average Simple Payback, years
$\$ 0.172$

$\$ 1.151$

The report provides analysis of two Life Cycle Cost (LCC) scenarios:

Scenario 1, representing publicly-owned buildings, considers initial costs, energy, maintenance and replacement costs without borrowing or taxes.

Scenario 2, representing privately-owned buildings, adds borrowing costs and tax impacts.

Table 2 shows the statewide weighted average LCC net present value of savings from both scenarios, that is, the remaining savings after initial and replacement costs have been paid for. Average values are weighted averages of all climate zones and building types in the state as shown in Table 6. Individual building type LCC results are shown in Figures 1 and 2.

Table 2. Utah Average LCC Results Weighted by Climate Zone and Building Type Weighted Net Life Cycle Cost Savings, by Ownership Scenario

Scenario 1 (Publicly-Owned), $\$ / \mathrm{ft}^{2}$ $\$ 2.06$

Scenario 2 (Privately-Owned), $\$ / \mathrm{ft}^{2}$

$\$ 2.57$

Figure 1. Scenario 1: Net Life Cycle Cost Savings

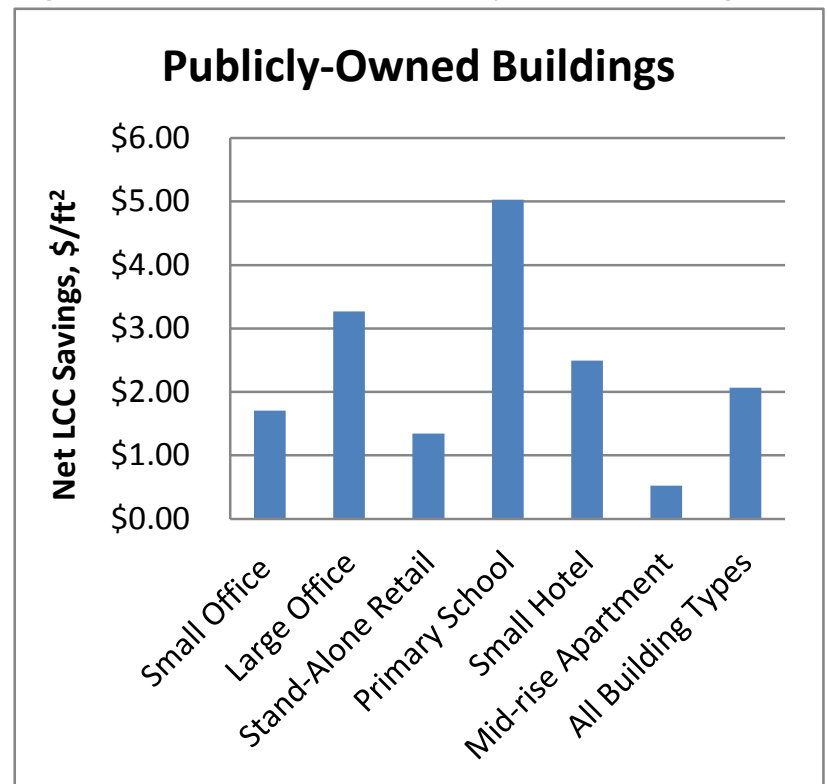

Figure 2. Scenario 2: Net Life Cycle Cost Savings

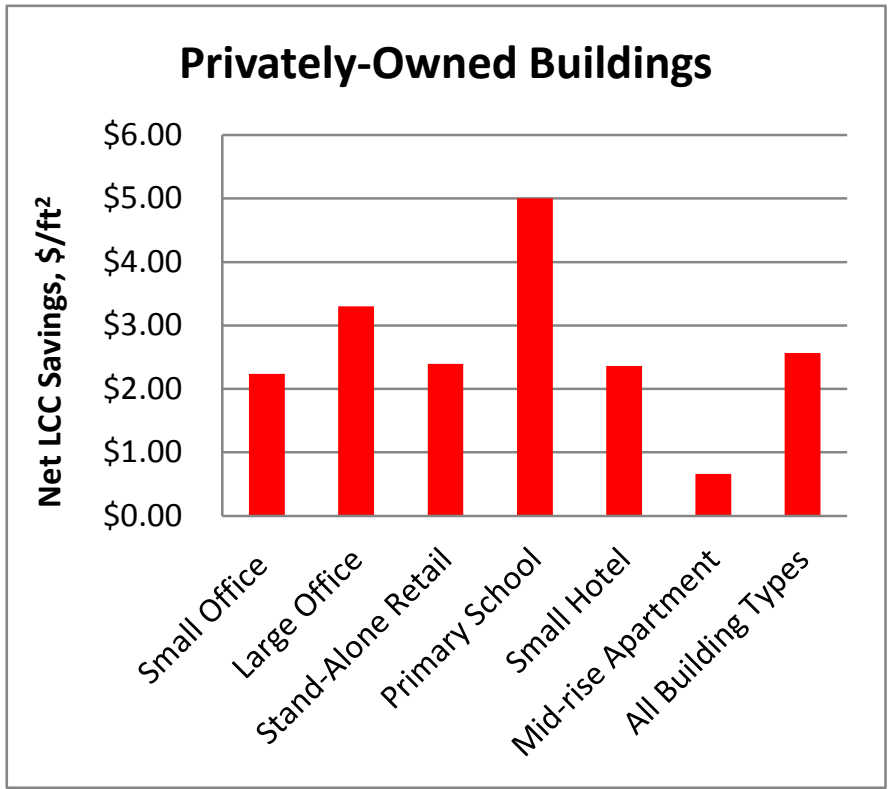




\section{Cost-Effectiveness Results for Standard 90.1-2010 in the State of Utah}

Life Cycle Cost (LCC) savings is the primary measure DOE uses to assess the economic impact of building energy codes.

Savings are computed for two scenarios:

Scenario 1 (publicly-owned) includes costs for initial equipment and construction, energy, maintenance and replacement and does not include loans or taxes.

Scenario 2 (privately-owned) includes the same costs as scenario 1 plus the initial investment is financed through a loan amortized over 30 years with corresponding tax deductions for interest and depreciation. Federal and state corporate income tax rates are applied.

Both scenarios include the residual value of equipment with remaining useful life at the end of the 30 years. Totals for building types, climate zones, and the state overall are averages base on Table 6 weightings.
Factors such as inflation and discount rates are different between the two scenarios, as described in the Cost-Effectiveness Methodology section.

Table 3 shows that the value today of the total LCC savings over 30 years for buildings in scenario 1 average \$2.06 per square foot for 90.1-2010. Table 4 shows that the LCC savings over 30 years average \$2.57 per square foot for scenario 2 . Table 5 shows that the primary benefit of ASHRAE Standard 90.1-2010, annual energy cost savings, average $\$ 0.172$ per square foot for both scenarios.

Table 3. LCC Savings (30 Years) from ASHRAE Standard 90.1-2010, Scenario $1\left(\$ / \mathrm{ft}^{2}\right)$

\begin{tabular}{|lccccccc|}
\hline $\begin{array}{c}\text { Climate Zone \& } \\
\text { Representative City }\end{array}$ & Small Office & Large Office & $\begin{array}{c}\text { Stand-Alone } \\
\text { Retail }\end{array}$ & $\begin{array}{c}\text { Primary } \\
\text { School }\end{array}$ & Small Hotel & $\begin{array}{c}\text { Mid-rise } \\
\text { Apartment }\end{array}$ & $\begin{array}{c}\text { All Building } \\
\text { Types }\end{array}$ \\
\hline 3B Saint George & $\$ 1.68$ & $\$ 2.25$ & $\$ 1.71$ & $\$ 5.81$ & $\$ 2.43$ & $\$ 0.54$ & $\$ 3.40$ \\
\hline 5B Salt Lake City & $\$ 1.72$ & $\$ 3.27$ & $\$ 1.32$ & $\$ 5.08$ & $\$ 2.49$ & $\$ 0.55$ & $\$ 2.02$ \\
\hline 6B Vernal & $\$ 1.50$ & $\$ 2.79$ & $\$ 1.60$ & $\$ 4.03$ & $\$ 2.56$ & $\$ 0.39$ & $\$ 1.85$ \\
\hline All Climate Zones & $\$ 1.70$ & $\$ 3.27$ & $\$ 1.35$ & $\$ 5.03$ & $\$ 2.50$ & $\$ 0.53$ & $\$ 2.06$ \\
\hline
\end{tabular}

Table 4. LCC Savings (30 Years) from ASHRAE Standard 90.1-2010, Scenario $2\left(\$ / \mathrm{ft}^{2}\right)$

\begin{tabular}{|c|c|c|c|c|c|c|c|}
\hline 5B Salt Lake City & $\$ 2.25$ & $\$ 3.30$ & $\$ 2.38$ & $\$ 5.03$ & $\$ 2.36$ & $\$ 0.69$ & $\$ 2.54$ \\
\hline 6B Vernal & $\$ 2.09$ & $\$ 3.09$ & $\$ 2.54$ & $\$ 4.30$ & $\$ 2.36$ & $\$ 0.52$ & $\$ 2.20$ \\
\hline All Climate Zones & $\$ 2.24$ & $\$ 3.30$ & $\$ 2.40$ & $\$ 5.00$ & $\$ 2.37$ & $\$ 0.66$ & $\$ 2.57$ \\
\hline
\end{tabular}

Table 5. Annual Energy Cost Savings from ASHRAE Standard 90.1-2010, Scenarios 1 and $2\left(\$ / \mathrm{ft}^{2}\right)$

\begin{tabular}{|lccccccc}
$\begin{array}{c}\text { Climate Zone \& } \\
\text { Representative City }\end{array}$ & Small Office & Large Office & $\begin{array}{c}\text { Stand-Alone } \\
\text { Retail }\end{array}$ & $\begin{array}{c}\text { Primary } \\
\text { School }\end{array}$ & $\begin{array}{c}\text { Small Hotel } \\
\begin{array}{c}\text { Mid-rise } \\
\text { Apartment }\end{array}\end{array} \begin{array}{c}\text { All Building } \\
\text { Types }\end{array}$ \\
\hline 3B Saint George & $\$ 0.159$ & $\$ 0.141$ & $\$ 0.209$ & $\$ 0.267$ & $\$ 0.123$ & $\$ 0.054$ \\
\hline 5B Salt Lake City & $\$ 0.162$ & $\$ 0.192$ & $\$ 0.204$ & $\$ 0.251$ & $\$ 0.110$ & $\$ 0.045$ & $\$ 0.172$ \\
\hline 6B Vernal & $\$ 0.160$ & $\$ 0.202$ & $\$ 0.205$ & $\$ 0.249$ & $\$ 0.102$ & $\$ 0.036$ & $\$ 0.143$ \\
\hline All Climate Zones & $\$ 0.162$ & $\$ 0.192$ & $\$ 0.204$ & $\$ 0.252$ & $\$ 0.110$ & $\$ 0.044$ & $\$ 0.172$ \\
\hline
\end{tabular}

The U.S. Department of Energy (DOE) provides estimates of energy and cost savings from code adoption at the National, Climate Zone, and State levels. For more information on how these estimates were developed, visit the DOE Building Energy Codes website: www.energycodes.gov/development/commercial

U.S Department of Energy

Energy Efficiency and Renewable Energy BUILDING TECHNOLOGIES OFFICE
EERE Information Center

1-877-EERE-INFO (1-877-337-3463)

www.eere.energy.gov/informationcenter

\section{Building Energy Codes}

For information on Building Energy

Codes, visit www.energycodes.gov 


\section{Costs and Weightings for Standard 90.1-2010 in the State of Utah}

\section{Construction Weighting of Results}

Energy and economic impacts were determined and reported separately for each building type and climate zone. Costeffectiveness results are also reported as averages for all prototypes and climate zones in the state. To determine these averages, results were combined across the different building types and climate zones using weighting factors shown in Table 6. These weighting factors are based on the floor area of new construction and major renovations for the six analyzed building prototypes in state-specific climate zones. The weighting factors were developed from construction start data from 2003 to 2007 based on an approach developed by Jarnagin and Bandyopadhyay (McGraw Hill Construction 2007, Jarnagin and Bandyopadhyay 2009).

Table 6. Construction Weights by Building Type

\begin{tabular}{|lcccccc|c|}
$\begin{array}{c}\text { Climate Zone \& } \\
\text { Representative City }\end{array}$ & $\begin{array}{c}\text { Small } \\
\text { Office }\end{array}$ & $\begin{array}{c}\text { Large } \\
\text { Office }\end{array}$ & $\begin{array}{c}\text { Stand-Alone } \\
\text { Retail }\end{array}$ & $\begin{array}{c}\text { Primary } \\
\text { School }\end{array}$ & $\begin{array}{c}\text { Small } \\
\text { Hotel }\end{array}$ & $\begin{array}{c}\text { Mid-rise } \\
\text { Apartment }\end{array}$ & $\begin{array}{c}\text { All Building } \\
\text { Types }\end{array}$ \\
\hline 3B Saint George & $0.8 \%$ & $0.0 \%$ & $1.4 \%$ & $1.7 \%$ & $0.4 \%$ & $0.0 \%$ \\
\hline 5B Salt Lake City & $13.4 \%$ & $6.5 \%$ & $35.2 \%$ & $14.1 \%$ & $2.3 \%$ & $16.2 \%$ & $87.7 \%$ \\
\hline 6B Vernal & $0.9 \%$ & $0.0 \%$ & $1.6 \%$ & $2.0 \%$ & $0.6 \%$ & $2.9 \%$ \\
\hline All Climate Zones & $15.1 \%$ & $6.5 \%$ & $38.2 \%$ & $17.8 \%$ & $3.4 \%$ & $19.0 \%$ & $100.0 \%$ \\
\hline
\end{tabular}

\section{Incremental Construction Cost}

Cost estimates were developed for the differences between the Base Code and ASHRAE Standard 90.1-2010 as implemented in the six prototype models. Costs for the initial construction include material, labor, commissioning, construction equipment, overhead and profit. These costs were developed using a commercial cost estimation firm, engineering design consultants and RS Means 2012 Cost Data (RS Means 2012a,b,c; 2004, Thornton et al. 2013).

Table 7 shows incremental initial cost for individual building types in state-specific climate zones and weighted average costs by climate zone and building type for moving to ASHRAE Standard 90.1-2010 from the Base Code. The incremental cost may be negative for some building types and climate zones based on the downsizing of HVAC equipment resulting from reductions in heating and cooling loads due to improvements in ASHRAE Standard 90.1-2010, such as more efficient lighting systems and changes in the building thermal envelope.

Table 7. Incremental Construction Cost of ASHRAE 90.1-2010 $\left(\$ / \mathrm{ft}^{2}\right)$

\begin{tabular}{|lccccccc}
$\begin{array}{c}\text { Climate Zone \& } \\
\text { Representative City }\end{array}$ & Small Office & Large Office & $\begin{array}{c}\text { Stand-Alone } \\
\text { Retail }\end{array}$ & $\begin{array}{c}\text { Primary } \\
\text { School }\end{array}$ & $\begin{array}{c}\text { Small Hotel } \\
\text { Apartment }\end{array}$ & $\begin{array}{c}\text { Mid-rise } \\
\text { All Building } \\
\text { Types }\end{array}$ \\
\hline 3B Saint George & $\$ 1.178$ & $(\$ 0.384)$ & $\$ 2.371$ & $(\$ 0.500)$ & $(\$ 0.176)$ & $\$ 0.462$ & $\$ 0.760$ \\
\hline 5B Salt Lake City & $\$ 1.200$ & $(\$ 0.423)$ & $\$ 2.591$ & $(\$ 0.196)$ & $(\$ 0.389)$ & $\$ 0.296$ & $\$ 1.205$ \\
\hline 6B Vernal & $\$ 1.306$ & $\$ 0.246$ & $\$ 2.376$ & $\$ 0.331$ & $(\$ 0.502)$ & $\$ 0.287$ & $\$ 0.770$ \\
\hline All Climate Zones & $\$ 1.205$ & $(\$ 0.423)$ & $\$ 2.574$ & $(\$ 0.165)$ & $(\$ 0.382)$ & $\$ 0.295$ & $\$ 1.151$ \\
\hline
\end{tabular}

Table 8 shows simple payback results in years. Simple payback is the number of years required for energy cost savings to exceed the incremental first costs of a new code or code change proposals. Simple payback is not used as a measure of cost-effectiveness as it does not account for the time value of money, the value of energy cost savings that occur after payback is achieved, or any maintenance or replacement costs that occur after the initial investment.

Table 8. Simple Payback from ASHRAE Standard 90.1-2010, Scenarios 1 and 2 (Years)

\begin{tabular}{|lcccccccc}
$\begin{array}{c}\text { Climate Zone \& } \\
\text { Representative City }\end{array}$ & $\begin{array}{c}\text { Small } \\
\text { Office }\end{array}$ & $\begin{array}{c}\text { Large } \\
\text { Office }\end{array}$ & $\begin{array}{c}\text { Stand-Alone } \\
\text { Retail }\end{array}$ & $\begin{array}{c}\text { Primary } \\
\text { School }\end{array}$ & $\begin{array}{c}\text { Small } \\
\text { Hotel }\end{array}$ & $\begin{array}{c}\text { Mid-rise } \\
\text { Apartment }\end{array}$ & $\begin{array}{c}\text { All Building } \\
\text { Types }\end{array}$ \\
\hline 3B Saint George & 7.4 & Immediate & 11.3 & Immediate & Immediate & 8.4 & 3.6 \\
\hline 5B Salt Lake City & 7.4 & Immediate & 12.7 & Immediate & Immediate & 6.6 & 7.0 \\
\hline 6B Vernal & 8.1 & 1.2 & 11.3 & 1.3 & Immediate & 7.9 & 5.4 \\
\hline All Climate Zones & 7.5 & Immediate & 12.6 & Immediate & Immediate & 6.8 & 6.7 \\
\hline
\end{tabular}




\section{Cost-Effectiveness Methodology for Standard 90.1 in the State of Utah}

LCC savings is the primary measure DOE uses to assess the cost-effectiveness of building energy codes.

\section{Cost-Effectiveness}

DOE uses standard economic Life Cycle Cost (LCC) cost-effectiveness analysis methods in comparing ASHRAE Standard 90.12010 and the Base Code.

LCC Savings: LCC is the calculation of the present value of costs over a 30-year period including initial equipment and construction costs, energy savings, maintenance and replacement costs, and residual value of components at the end of the 30 year period. A separate LCC is determined for the Base Code and for ASHRAE Standard 90.1-2010. The LCC savings is the Base Code LCC minus the ASHRAE Standard 90.1-2010 LCC. Two cost scenarios are analyzed:

Scenario 1 includes the costs listed above without borrowing or taxes.

Scenario 2 incudes the same costs as scenario 1 plus financing of the incremental costs through increased borrowing with associated tax impacts including mortgage interest deductions and depreciation. Corporate tax rates are applied.

Economic analysis factors such as discount rates are also different, as described in Table 10.

While not a true cost-effectiveness metric, Simple Payback is also calculated. Simple payback is the number of years required for accumulated annual energy cost savings to exceed the incremental first costs of a new code.

This analysis demonstrates that for all building types and climate zones in the State of Utah, ASHRAE Standard 90.1-2010 results in savings over the Base Code (ASHRAE Standard 90.1-2007).

Hence, ASHRAE Standard 90.1-2010 is cost-effective in the State of Utah.

The cost-effectiveness analysis compares the cost for new buildings meeting ASHRAE Standard 90.1-2010 compared to new buildings meeting a Base Code, ASHRAE Standard 90.1-2007 (ASHRAE 2010, ASHRAE 2007). The analysis includes energy savings estimates from building energy simulations and life cycle cost (LCC) and simple payback calculations using standard economic analysis parameters. The analysis builds on work documented in Achieving the 30\% Goal: Energy and Cost Savings Analysis of ASHRAE Standard 90.1-2010 (Thornton et al. 2011), and the cost-effectiveness analysis documented in Cost-effectiveness of ASHRAE Standard 90.1-2010 Compared to ASHRAE Standard 90.1-2007 (Thornton et al. 2013).

\section{Building Prototypes and Energy Modeling}

The cost-effectiveness analysis uses six building types represented by six "prototype" building energy models. These six are a subset of 16 prototype building energy models and represent $80 \%$ of commercial floor space. These models provide coverage of the significant changes in ASHRAE Standard 90.1 from 2007 to 2010 and are used to show the impacts of the changes on energy savings. The prototypes represent common construction practice and include the primary conventional heating, ventilating and air-conditioning (HVAC) systems most commonly used in commercial buildings. More information on the prototype buildings and savings analysis can be found at: www.energycodes.gov/development/commercial/90.1 models.

Each prototype building is analyzed for each of the climate zones found within the state. Using the U.S. Department of Energy (DOE) EnergyPlus ${ }^{\mathrm{TM}}$ software, the six building prototypes summarized in Table 9 are simulated with characteristics meeting the requirements of the Base Code (ASHRAE Standard 90.1-2007) and then modified to meet the requirements of the next edition of the code (ASHRAE Standard 90.1-2010). The energy use and cost is then compared between the two sets of models.

Table 9. Building Prototypes

\begin{tabular}{|ccc|}
\hline Building Prototype & Floor Area $\mathbf{f t}^{\mathbf{2}} \mathbf{)}$ & Number of Floors \\
Small Office & 5,500 & 1 \\
Large Office & 498,640 & 13 \\
Stand-Alone Retail & 24,690 & 1 \\
Primary School & 73,970 & 1 \\
Small Hotel & 43,210 & 4 \\
Mid-rise Apartment & 33,740 & 4 \\
\hline
\end{tabular}

\section{Climate Zones}

Climate zones are defined in ASHRAE Standard 90.1 and include eight primary climate zones, the hottest being climate zone 1 and the coldest being climate zone 8. Letters $A, B$, and $C$ are applied in some cases to denote the level of moisture, with $A$ indicating moist or humid, B indicating dry, and C indicating marine. Figure 3 shows the national climate zones. For this state analysis, savings is analyzed for each climate zone in the state using weather data from a selected city within the climate zone and state, or where necessary, a city in an adjoining state with more robust weather data. The cities used are shown in Tables 3 through 8. 


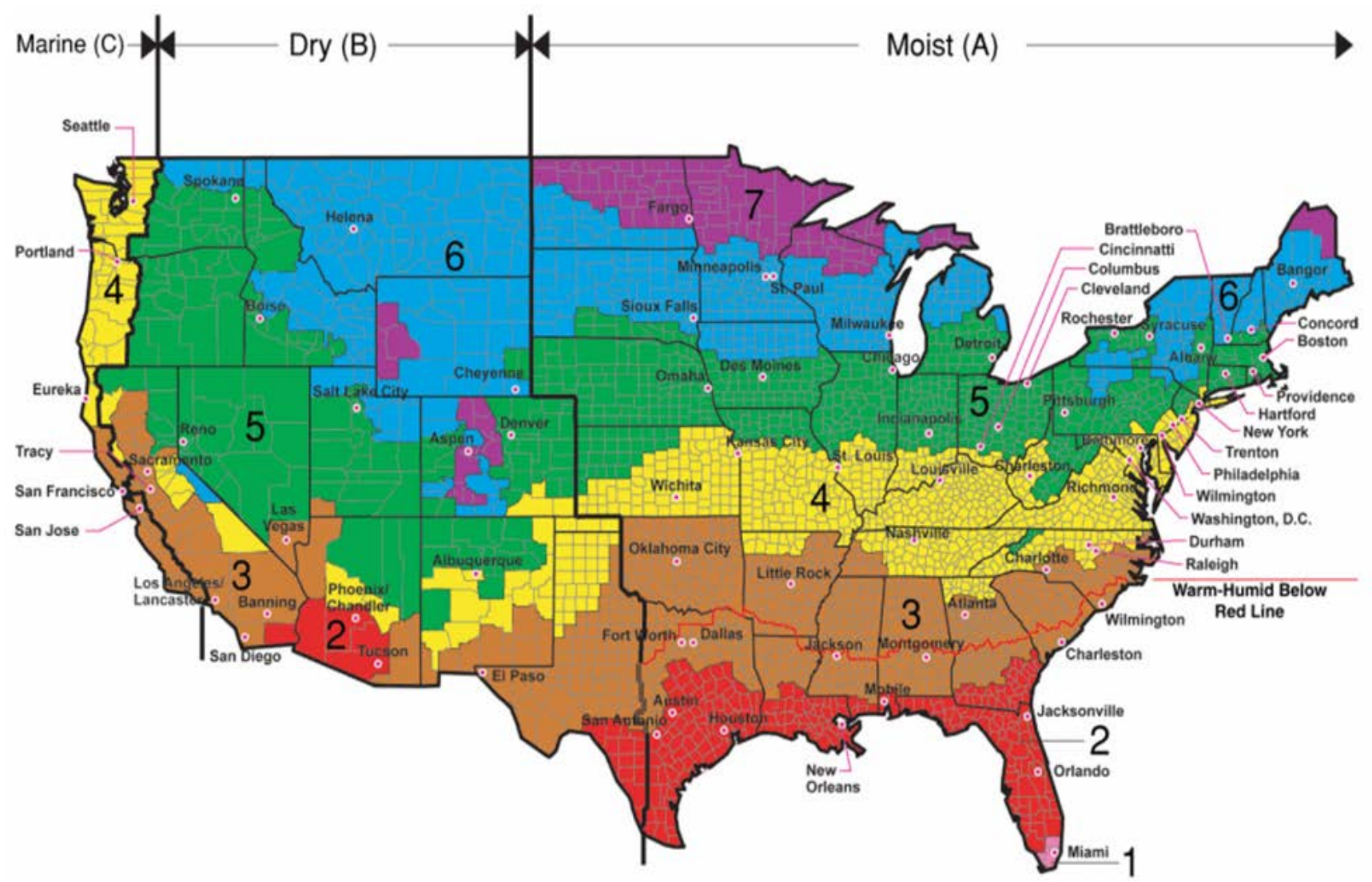

All of Alaska in Zone 7 except for the following Boroughs in Zone 8: Bethel, Dellingham, Fairbanks, N. Star, Nome North Slope, Northwest Arctic, Southeast Fairbanks, Wade Hampton, and Yukon-Koyukuk

Zone 1 includes: Hawail, Guam, Puerto Rico, and the Virgin Islands

Figure 3. National Climate Zones

The DOE cost-effectiveness methodology accounts for the benefits of energy-efficient building construction over a multi-year analysis period, balancing initial costs against longer term energy savings. DOE evaluates energy codes and code proposals based on LCC analysis over a multi-year study period, accounting for energy savings, incremental investment for energy efficiency measures, and other economic impacts. The value of future savings and costs are discounted to a present value, with improvements deemed cost-effective when the net savings (savings minus cost) is positive.

The U.S. DOE Building Technologies Office (BTO) uses an LCC analysis similar to the method used for many federal building projects, as well as other public and private building projects (Fuller and Petersen 1995). The LCC analysis method consists of identifying costs (and revenues if any) and in what year they occur, and determining their value in today's dollars (known as the present value). This method uses fundamental engineering economics relationships about the time value of money (money today is normally worth more than money tomorrow, which is why we pay interest on a loan, and earn interest on savings). Future costs are discounted to the present based on a discount rate. The discount rate may reflect the interest rate at which money can be borrowed for projects with the same level of risk or the interest rate that can be earned on other conventional investments with similar risk.

The LCC for both scenarios includes incremental initial costs, repairs, maintenance and replacements. Scenario 2 also includes loan costs and tax impacts including interest deduction and depreciation. The residual value of equipment (or other component such as roof membrane) that has remaining useful life at end of the 30-year study period is also included for both scenarios. The residual value is calculated by multiplying the initial cost of the component by the years of useful life remaining for the component at year 30 divided by the total useful life, a simplified approach included in the Federal Energy Management Program (FEMP) LCC method (Fuller and Petersen 1995). The component in place at year 30 may be the original component if it has a longer than 30 -year life or equipment that has already been replaced one or more times during the 30-year period that has a useful life that does not divide evenly into 30 years.

The financial and economic parameters used for the LCC calculations are shown in Table 10. 
Table 10. LCC Economic Parameters

\begin{tabular}{|c|c|c|}
\hline Economic Parameter & Scenario 1 & Scenario 2 \\
\hline Study Period - Years ${ }^{1}$ & 30 & 30 \\
\hline Nominal Discount Rate ${ }^{2}$ & $3.90 \%$ & $6.00 \%$ \\
\hline Real Discount Rate ${ }^{2}$ & $3.00 \%$ & $4.60 \%$ \\
\hline Inflation $^{3}$ & $0.90 \%$ & $1.30 \%$ \\
\hline Electricity Prices ${ }^{4}$ & $\$ 0.0805$ & $\$ 0.0805$ \\
\hline Natural Gas Prices ${ }^{4}$ & $\$ 0.6900$ & $\$ 0.6900$ \\
\hline Energy Price Escalation Factors ${ }^{5}$ & $\begin{array}{c}\text { Uniform present } \\
\text { value factors }\end{array}$ & $\begin{array}{c}\text { Annual escalation } \\
\text { factors }\end{array}$ \\
\hline Electricity Price Escalation ${ }^{5}$ & 18.88 & $1.50 \% /$ year \\
\hline Natural Gas Price Escalation ${ }^{5}$ & 20.90 & $2.72 \% /$ year \\
\hline Loan Interest Rate ${ }^{6}$ & NA & $6.00 \%$ \\
\hline Federal Corporate Tax Rate ${ }^{7}$ & NA & $34.00 \%$ \\
\hline State Corporate Tax Rate ${ }^{8}$ & NA & $5.00 \%$ \\
\hline Combined Income Tax Impact $^{9}$ & NA & $37.30 \%$ \\
\hline State and Average Local Sales Tax ${ }^{10}$ & $6.70 \%$ & $6.70 \%$ \\
\hline
\end{tabular}

${ }^{1}$ A 30-year study period captures most building components useful lives and is a commonly used study period for building project economic analysis. This period is consistent with previous and related National 90.1 cost-effectiveness analysis (Thornton et al. 2013). It is also consistent with the cost-effectiveness analysis that was done for the residential energy code as described in multiple state reports and a summary report (DOE 2012). The federal building LCC method uses 25 years and the ASHRAE Standard 90.1 development process uses up to 40 years for building envelope code improvement analysis. Because of the time value of money, results are typically similar for any study periods of 20 years or more.

2 The scenario 1 real and nominal discount rates are from the National Institute of Standards and Technology (NIST) 2011 annual LCC update for the federal LCC method (Rushing et al. 2011). The scenario 2 nominal discount rate is assumed to be the marginal cost of capital, which is set equal to the assumed loan interest rate (see footnote 6). The real discount rate is calculated from the nominal discount rate and inflation.

${ }^{3}$ The scenario 1 effective inflation rate is from the NIST 2011 annual LCC update for the federal LCC method (Rushing et al. 2011) consistent with the ASHRAE Standard 90.1 national cost-effectiveness analysis 30-year LCC analysis (Thornton et al. 2013). The scenario 2 inflation rate is the Producer Price Index for non-residential construction, February 2012 to February 2013 (Bureau of Labor Statistics 2013).

${ }^{4}$ Scenario 1 and 2 electricity and natural gas prices are state average prices from the United States Energy Information Agency (EIA) Energy Outlook 2012 (EIA 2012).

${ }^{5}$ Scenario 1 energy price escalation rates are from NIST 2011 annual update for the FEMP LCC method (Rushing et al. 2011) consistent with the ASHRAE Standard 90.1 national cost-effectiveness 30-year LCC analysis (Thornton et al. 2013). The NIST uniform present value factors are multiplied by the first year annual energy cost to determine the present value of 30 years of energy costs and are based on a series of different annual escalation rates for 30 years. Scenario 2 uses national average annual real electricity price escalation rates for 2011 to 2040 (EIA 2013), 0.2\% for electricity and 1.4\% for natural gas. EIA publishes regional, but not statespecific, escalation rates; the regional rates are estimates and thought to not add additional accuracy to the state-level economic estimates. The effective nominal escalation rates calculated using the scenario 2 inflation rate of $1.3 \%$ are shown in the table above.

${ }^{6}$ The loan interest rate is estimated from multiple online sources listed in the references (Capital Funders 2012, Commercial Loan Direct 2013, and Steelhead Capital 2013).

7 The highest federal marginal corporate income tax rate is assumed to apply.

8 The highest marginal state corporate income tax rate is assumed to apply from the Federation of Tax Administrators (FTA 2013).

${ }^{9}$ The combined tax impact is based on state tax being a deduction for federal tax, and is applied to depreciation and loan interest.

${ }^{10}$ The state and average local sales tax is included in material costs in the cost estimate.

\section{Detailed Energy Use and Cost}

On the following pages, specific detailed results for Utah are included:

Table 11 shows the average energy rates used.

Table 12 shows the per square foot energy costs for 90.1-2007 and 90.1-2010 and the cost savings from 90.1-2010.

Table 13 shows the per square foot energy use for 90.1-2007 and 90.1-2010 and the use savings from 90.1-2010.

Tables 14.A through 14.C show the energy end use by energy type for each climate zone in the state. 
Table 11. Energy Rates for the State of Utah, Average \$ per unit

\begin{tabular}{|ccc|}
\hline Electricity & $\$ 0.0805$ & $\mathrm{kWh}$ \\
Gas & $\$ 0.6900$ & therm \\
\hline
\end{tabular}

Source: Energy Information Administration (EIA 2012)

Table 12. Energy Cost Saving Results for ASHRAE Standard 90.1 in the State of Utah, $\mathbf{\$}$ per square foot

\begin{tabular}{|c|c|c|c|c|c|c|c|c|c|c|c|c|}
\hline \multirow{2}{*}{$\begin{array}{l}\text { Climate Zone: } \\
\text { Code: }\end{array}$} & \multicolumn{4}{|c|}{ 3B } & \multicolumn{4}{|c|}{$5 B$} & \multicolumn{4}{|c|}{$6 \mathrm{~B}$} \\
\hline & $90.1-2007$ & $90.1-2010$ & Savings & & $90.1-2007$ & $90.1-2010$ & Savings & & $90.1-2007$ & $90.1-2010$ & Savings & \\
\hline \multicolumn{13}{|l|}{ Small Office } \\
\hline Electricity & $\$ 0.913$ & $\$ 0.754$ & $\$ 0.159$ & $17.4 \%$ & $\$ 0.914$ & $\$ 0.753$ & $\$ 0.161$ & $17.6 \%$ & $\$ 0.900$ & $\$ 0.740$ & $\$ 0.160$ & $17.8 \%$ \\
\hline Gas & $\$ 0.000$ & $\$ 0.000$ & $\$ 0.000$ & - & $\$ 0.001$ & $\$ 0.001$ & $\$ 0.000$ & $0.0 \%$ & $\$ 0.004$ & $\$ 0.003$ & $\$ 0.001$ & $25.0 \%$ \\
\hline Totals & $\$ 0.913$ & $\$ 0.754$ & $\$ 0.159$ & $17.4 \%$ & $\$ 0.916$ & $\$ 0.754$ & $\$ 0.162$ & $17.7 \%$ & $\$ 0.903$ & $\$ 0.743$ & $\$ 0.160$ & $17.7 \%$ \\
\hline \multicolumn{13}{|l|}{ Large Office } \\
\hline Electricity & $\$ 1.841$ & $\$ 1.707$ & $\$ 0.134$ & $7.3 \%$ & $\$ 1.810$ & $\$ 1.632$ & $\$ 0.178$ & $9.8 \%$ & $\$ 1.810$ & $\$ 1.617$ & $\$ 0.192$ & $10.6 \%$ \\
\hline Gas & $\$ 0.019$ & $\$ 0.012$ & $\$ 0.007$ & $36.8 \%$ & $\$ 0.047$ & $\$ 0.033$ & $\$ 0.014$ & $29.8 \%$ & $\$ 0.051$ & $\$ 0.041$ & $\$ 0.009$ & $17.6 \%$ \\
\hline Totals & $\$ 1.860$ & $\$ 1.719$ & $\$ 0.141$ & $7.6 \%$ & $\$ 1.856$ & $\$ 1.665$ & $\$ 0.192$ & $10.3 \%$ & $\$ 1.860$ & $\$ 1.658$ & $\$ 0.202$ & $10.9 \%$ \\
\hline \multicolumn{13}{|c|}{ Stand-Alone Retail } \\
\hline Electricity & $\$ 1.273$ & $\$ 1.052$ & $\$ 0.220$ & $17.3 \%$ & $\$ 1.200$ & $\$ 0.980$ & $\$ 0.220$ & $18.3 \%$ & $\$ 1.183$ & $\$ 0.964$ & $\$ 0.219$ & $18.5 \%$ \\
\hline Gas & $\$ 0.048$ & $\$ 0.059$ & $-\$ 0.011$ & $-22.9 \%$ & $\$ 0.089$ & $\$ 0.105$ & $-\$ 0.016$ & $-18.0 \%$ & $\$ 0.102$ & $\$ 0.116$ & $-\$ 0.014$ & $-13.7 \%$ \\
\hline Totals & $\$ 1.321$ & $\$ 1.111$ & $\$ 0.209$ & $15.8 \%$ & $\$ 1.289$ & $\$ 1.085$ & $\$ 0.204$ & $15.8 \%$ & $\$ 1.284$ & $\$ 1.080$ & $\$ 0.205$ & $16.0 \%$ \\
\hline \multicolumn{13}{|l|}{ Primary School } \\
\hline Electricity & $\$ 1.231$ & $\$ 1.000$ & $\$ 0.231$ & $18.8 \%$ & $\$ 1.147$ & $\$ 0.950$ & $\$ 0.197$ & $17.2 \%$ & $\$ 1.126$ & $\$ 0.940$ & $\$ 0.186$ & $16.5 \%$ \\
\hline Gas & $\$ 0.095$ & $\$ 0.059$ & $\$ 0.036$ & $37.9 \%$ & $\$ 0.135$ & $\$ 0.081$ & $\$ 0.054$ & $40.0 \%$ & $\$ 0.151$ & $\$ 0.089$ & $\$ 0.062$ & $41.1 \%$ \\
\hline Totals & $\$ 1.326$ & $\$ 1.059$ & $\$ 0.267$ & $20.1 \%$ & $\$ 1.283$ & $\$ 1.031$ & $\$ 0.251$ & $19.6 \%$ & $\$ 1.278$ & $\$ 1.029$ & $\$ 0.249$ & $19.5 \%$ \\
\hline \multicolumn{13}{|l|}{ Small Hotel } \\
\hline Electricity & $\$ 1.038$ & $\$ 0.914$ & $\$ 0.124$ & $11.9 \%$ & $\$ 1.006$ & $\$ 0.894$ & $\$ 0.112$ & $11.1 \%$ & $\$ 1.006$ & $\$ 0.901$ & $\$ 0.104$ & $10.3 \%$ \\
\hline Gas & $\$ 0.142$ & $\$ 0.143$ & $-\$ 0.001$ & $-0.7 \%$ & $\$ 0.160$ & $\$ 0.162$ & $-\$ 0.002$ & $-1.3 \%$ & $\$ 0.168$ & $\$ 0.170$ & $-\$ 0.002$ & $-1.2 \%$ \\
\hline Totals & $\$ 1.180$ & $\$ 1.057$ & $\$ 0.123$ & $10.4 \%$ & $\$ 1.166$ & $\$ 1.055$ & $\$ 0.110$ & $9.4 \%$ & $\$ 1.174$ & $\$ 1.071$ & $\$ 0.102$ & $8.7 \%$ \\
\hline \multicolumn{13}{|c|}{ Mid-rise Apartment } \\
\hline Electricity & $\$ 1.029$ & $\$ 0.975$ & $\$ 0.054$ & $5.2 \%$ & $\$ 0.984$ & $\$ 0.950$ & $\$ 0.034$ & $3.5 \%$ & $\$ 0.971$ & $\$ 0.941$ & $\$ 0.030$ & $3.1 \%$ \\
\hline Gas & $\$ 0.008$ & $\$ 0.008$ & $\$ 0.001$ & $12.5 \%$ & $\$ 0.048$ & $\$ 0.038$ & $\$ 0.010$ & $20.8 \%$ & $\$ 0.050$ & $\$ 0.045$ & $\$ 0.006$ & $12.0 \%$ \\
\hline Totals & $\$ 1.037$ & $\$ 0.983$ & $\$ 0.054$ & $5.2 \%$ & $\$ 1.032$ & $\$ 0.988$ & $\$ 0.045$ & $4.4 \%$ & $\$ 1.022$ & $\$ 0.986$ & $\$ 0.036$ & $3.5 \%$ \\
\hline
\end{tabular}


Table 13. Energy Use Saving Results for ASHRAE Standard 90.1 in the State of Utah, Energy Use per Square Foot

\begin{tabular}{|c|c|c|c|c|c|c|c|c|c|c|c|c|}
\hline \multirow{2}{*}{$\begin{array}{l}\text { Climate Zone: } \\
\text { Code: }\end{array}$} & \multicolumn{4}{|c|}{ 3B } & \multicolumn{4}{|c|}{$5 B$} & \multicolumn{4}{|c|}{$6 \mathrm{~B}$} \\
\hline & $90.1-2007$ & $90.1-2010$ & Savings & & $90.1-2007$ & $90.1-2010$ & Savings & & $90.1-2007$ & $90.1-2010$ & Savings & \\
\hline \multicolumn{13}{|l|}{ Small Office } \\
\hline Electricity, kWh/ft ${ }^{2}$ & 11.339 & 9.367 & 1.972 & $17.4 \%$ & 11.359 & 9.355 & 2.005 & $17.7 \%$ & 11.175 & 9.189 & 1.985 & $17.8 \%$ \\
\hline Gas, therm $/ \mathrm{ft}^{2}$ & 0.000 & 0.000 & 0.000 & - & 0.002 & 0.002 & 0.001 & $50.0 \%$ & 0.005 & 0.004 & 0.001 & $20.0 \%$ \\
\hline Totals, kBtu/ft ${ }^{2}$ & 38.725 & 32.001 & 6.724 & $17.4 \%$ & 38.986 & 32.091 & 6.895 & $17.7 \%$ & 38.656 & 31.791 & 6.866 & $17.8 \%$ \\
\hline \multicolumn{13}{|l|}{ Large Office } \\
\hline Electricity, $\mathrm{kWh} / \mathrm{ft}^{2}$ & 22.866 & 21.200 & 1.665 & $7.3 \%$ & 22.482 & 20.273 & 2.209 & $9.8 \%$ & 22.479 & 20.090 & 2.389 & $10.6 \%$ \\
\hline Gas, therm $/ \mathrm{ft}^{2}$ & 0.027 & 0.018 & 0.010 & $37.0 \%$ & 0.068 & 0.048 & 0.020 & $29.4 \%$ & 0.073 & 0.059 & 0.014 & $19.2 \%$ \\
\hline Totals, kBtu/ft ${ }^{2}$ & 80.781 & 74.122 & 6.659 & $8.2 \%$ & 83.489 & 73.952 & 9.537 & $11.4 \%$ & 84.039 & 74.515 & 9.524 & $11.3 \%$ \\
\hline \multicolumn{13}{|l|}{ Stand-Alone Retail } \\
\hline Electricity, $\mathrm{kWh} / \mathrm{ft}^{2}$ & 15.809 & 13.074 & 2.735 & $17.3 \%$ & 14.909 & 12.176 & 2.733 & $18.3 \%$ & 14.693 & 11.973 & 2.720 & $18.5 \%$ \\
\hline Gas, therm $/ \mathrm{ft}^{2}$ & 0.069 & 0.085 & -0.016 & $-23.2 \%$ & 0.129 & 0.152 & -0.023 & $-17.8 \%$ & 0.147 & 0.168 & -0.021 & $-14.3 \%$ \\
\hline Totals, kBtu/ft ${ }^{2}$ & 60.901 & 53.133 & 7.768 & $12.8 \%$ & 63.791 & 56.756 & 7.035 & $11.0 \%$ & 64.883 & 57.651 & 7.232 & $11.1 \%$ \\
\hline \multicolumn{13}{|l|}{ Primary School } \\
\hline Electricity, $\mathrm{kWh} / \mathrm{ft}^{2}$ & 15.287 & 12.422 & 2.865 & $18.7 \%$ & 14.252 & 11.803 & 2.449 & $17.2 \%$ & 13.990 & 11.675 & 2.315 & $16.5 \%$ \\
\hline Gas, therm $/ \mathrm{ft}^{2}$ & 0.138 & 0.086 & 0.052 & $37.7 \%$ & 0.196 & 0.117 & 0.079 & $40.3 \%$ & 0.219 & 0.129 & 0.090 & $41.1 \%$ \\
\hline Totals, $\mathrm{kBtu} / \mathrm{ft}^{2}$ & 65.935 & 50.946 & 14.990 & $22.7 \%$ & 68.245 & 52.028 & 16.217 & $23.8 \%$ & 69.676 & 52.731 & 16.945 & $24.3 \%$ \\
\hline \multicolumn{13}{|l|}{ Small Hotel } \\
\hline Electricity, $\mathrm{kWh} / \mathrm{ft}^{2}$ & 12.895 & 11.355 & 1.540 & $11.9 \%$ & 12.492 & 11.104 & 1.388 & $11.1 \%$ & 12.492 & 11.194 & 1.298 & $10.4 \%$ \\
\hline Gas, therm/ $/ \mathrm{ft}^{2}$ & 0.206 & 0.207 & -0.001 & $-0.5 \%$ & 0.232 & 0.234 & -0.002 & $-0.9 \%$ & 0.244 & 0.247 & -0.003 & $-1.2 \%$ \\
\hline Totals, kBtu/ft ${ }^{2}$ & 64.595 & 59.455 & 5.140 & $8.0 \%$ & 65.817 & 61.305 & 4.512 & $6.9 \%$ & 66.998 & 62.884 & 4.114 & $6.1 \%$ \\
\hline \multicolumn{13}{|l|}{ Mid-rise Apartment } \\
\hline Electricity, $\mathrm{kWh} / \mathrm{ft}^{2}$ & 12.779 & 12.111 & 0.668 & $5.2 \%$ & 12.228 & 11.801 & 0.427 & $3.5 \%$ & 12.066 & 11.693 & 0.374 & $3.1 \%$ \\
\hline Gas, therm/ $\mathrm{ft}^{2}$ & 0.012 & 0.011 & 0.001 & $8.3 \%$ & 0.069 & 0.055 & 0.015 & $21.7 \%$ & 0.073 & 0.065 & 0.008 & $11.0 \%$ \\
\hline Totals, kBtu/ft ${ }^{2}$ & 44.846 & 42.481 & 2.364 & $5.3 \%$ & 48.659 & 45.728 & 2.931 & $6.0 \%$ & 48.481 & 46.378 & 2.102 & $4.3 \%$ \\
\hline
\end{tabular}


Table 14.A. Annual Energy Usage for Buildings in the State of Utah in Climate Zone 3B

\begin{tabular}{|c|c|c|c|c|c|c|c|c|c|c|c|c|}
\hline \multirow{2}{*}{$\begin{array}{l}\text { Energy } \\
\text { End-Use }\end{array}$} & \multicolumn{2}{|c|}{ Small Office } & \multicolumn{2}{|c|}{ Large Office } & \multicolumn{2}{|c|}{ Stand-Alone Retail } & \multicolumn{2}{|c|}{ Primary School } & \multicolumn{2}{|c|}{ Small Hotel } & \multicolumn{2}{|c|}{ Mid-rise Apartment } \\
\hline & $\begin{array}{l}\text { Electric } \\
\mathrm{kWh} / \\
\mathrm{ft}^{2} \cdot \mathrm{yr} \\
\end{array}$ & $\begin{array}{c}\text { Gas } \\
\text { therms/ } \\
\mathrm{ft}^{2} \cdot \mathrm{yr} \\
\end{array}$ & $\begin{array}{l}\text { Electric } \\
\mathrm{kWh} / \\
\mathrm{ft}^{2} \cdot \mathrm{yr} \\
\end{array}$ & $\begin{array}{c}\text { Gas } \\
\text { therms/ } \\
\mathrm{ft}^{2} \cdot \mathrm{yr} \\
\end{array}$ & $\begin{array}{l}\text { Electric } \\
\mathrm{kWh} / \\
\mathrm{ft}^{2} \cdot \mathrm{yr} \\
\end{array}$ & $\begin{array}{c}\text { Gas } \\
\text { therms/ } \\
\mathrm{ft}^{2} \cdot \mathrm{yr} \\
\end{array}$ & $\begin{array}{l}\text { Electric } \\
\mathrm{kWh} / \\
\mathrm{ft}^{2} \cdot \mathrm{yr} \\
\end{array}$ & $\begin{array}{c}\text { Gas } \\
\text { therms/ } \\
\mathrm{ft}^{2} \cdot \mathrm{yr} \\
\end{array}$ & $\begin{array}{l}\text { Electric } \\
\mathrm{kWh} / \\
\mathrm{ft}^{2} \cdot \mathrm{yr} \\
\end{array}$ & $\begin{array}{c}\text { Gas } \\
\text { therms/ } \\
\mathrm{ft}^{2} \cdot \mathrm{yr}\end{array}$ & $\begin{array}{l}\text { Electric } \\
\mathrm{kWh} / \\
\mathrm{ft}^{2} \cdot \mathrm{yr}\end{array}$ & $\begin{array}{c}\text { Gas } \\
\text { therms/ } \\
\mathrm{ft}^{2} \cdot \mathrm{yr} \\
\end{array}$ \\
\hline \multicolumn{13}{|l|}{ Base Code: 90.1-2007 } \\
\hline Heating, Humidification & 0.111 & 0.000 & 0.574 & 0.019 & 0.000 & 0.034 & 0.000 & 0.078 & 0.213 & 0.002 & 0.000 & 0.012 \\
\hline Cooling & 1.389 & 0.000 & 4.091 & 0.000 & 3.072 & 0.000 & 3.119 & 0.000 & 2.954 & 0.000 & 1.872 & 0.000 \\
\hline Fans, Pumps, Heat Recovery & 1.382 & 0.000 & 2.035 & 0.000 & 3.734 & 0.000 & 1.757 & 0.000 & 2.044 & 0.000 & 2.363 & 0.000 \\
\hline Lighting, Interior \& Exterior & 4.880 & 0.000 & 3.413 & 0.000 & 6.807 & 0.000 & 4.864 & 0.000 & 3.814 & 0.000 & 1.426 & 0.000 \\
\hline Plugs, Refrigeration, Other & 2.666 & 0.000 & 12.753 & 0.000 & 2.196 & 0.000 & 5.442 & 0.046 & 3.870 & 0.092 & 4.262 & 0.000 \\
\hline Service Water Heating (SWH) & 0.911 & 0.000 & 0.000 & 0.009 & 0.000 & 0.035 & 0.105 & 0.014 & 0.000 & 0.111 & 2.857 & 0.000 \\
\hline Total & 11.339 & 0.000 & 22.866 & 0.027 & 15.809 & 0.069 & 15.287 & 0.138 & 12.895 & 0.206 & 12.779 & 0.012 \\
\hline \multicolumn{13}{|l|}{ ASHRAE 90.1-2010 } \\
\hline Heating, Humidification & 0.124 & 0.000 & 1.478 & 0.009 & 0.000 & 0.051 & 0.000 & 0.026 & 0.245 & 0.004 & 0.000 & 0.011 \\
\hline Cooling & 1.248 & 0.000 & 3.109 & 0.000 & 2.441 & 0.000 & 2.237 & 0.000 & 2.462 & 0.000 & 1.773 & 0.000 \\
\hline Fans, Pumps, Heat Recovery & 1.277 & 0.000 & 1.776 & 0.000 & 2.681 & 0.000 & 1.531 & 0.000 & 1.920 & 0.000 & 2.082 & 0.000 \\
\hline Lighting, Interior \& Exterior & 3.334 & 0.000 & 2.511 & 0.000 & 5.762 & 0.000 & 3.231 & 0.000 & 2.928 & 0.000 & 1.189 & 0.000 \\
\hline Plugs, Refrigeration, Other & 2.474 & 0.000 & 12.326 & 0.000 & 2.190 & 0.000 & 5.326 & 0.046 & 3.799 & 0.092 & 4.211 & 0.000 \\
\hline Service Water Heating (SWH) & 0.910 & 0.000 & 0.000 & 0.009 & 0.000 & 0.035 & 0.097 & 0.014 & 0.000 & 0.111 & 2.857 & 0.000 \\
\hline Total & 9.367 & 0.000 & 21.200 & 0.018 & 13.074 & 0.085 & 12.422 & 0.086 & 11.355 & 0.207 & 12.111 & 0.011 \\
\hline Total Savings & 1.972 & 0.000 & 1.665 & 0.010 & 2.735 & -0.016 & 2.865 & 0.052 & 1.540 & -0.001 & 0.668 & 0.001 \\
\hline
\end{tabular}


Table 14.B. Annual Energy Usage for Buildings in the State of Utah in Climate Zone 5B

\begin{tabular}{|c|c|c|c|c|c|c|c|c|c|c|c|c|}
\hline \multirow{2}{*}{$\begin{array}{l}\text { Energy } \\
\text { End-Use }\end{array}$} & \multicolumn{2}{|c|}{ Small Office } & \multicolumn{2}{|c|}{ Large Office } & \multicolumn{2}{|c|}{ Stand-Alone Retail } & \multicolumn{2}{|c|}{ Primary School } & \multicolumn{2}{|c|}{ Small Hotel } & \multicolumn{2}{|c|}{ Mid-rise Apartment } \\
\hline & $\begin{array}{l}\text { Electric } \\
\mathrm{kWh} / \\
\mathrm{ft}^{2} \cdot \mathrm{yr}\end{array}$ & $\begin{array}{c}\text { Gas } \\
\text { therms/ } \\
\mathrm{ft}^{2} \cdot \mathrm{yr} \\
\end{array}$ & $\begin{array}{l}\text { Electric } \\
\mathrm{kWh} / \\
\mathrm{ft}^{2} \cdot \mathrm{yr}\end{array}$ & $\begin{array}{c}\text { Gas } \\
\text { therms/ } \\
\mathrm{ft}^{2} \cdot \mathrm{yr}\end{array}$ & $\begin{array}{l}\text { Electric } \\
\mathrm{kWh} / \\
\mathrm{ft}^{2} \cdot \mathrm{yr}\end{array}$ & $\begin{array}{c}\text { Gas } \\
\text { therms/ } \\
\mathrm{ft}^{2} \cdot \mathrm{yr}\end{array}$ & $\begin{array}{l}\text { Electric } \\
\mathrm{kWh} / \\
\mathrm{ft}^{2} \cdot \mathrm{yr}\end{array}$ & $\begin{array}{c}\text { Gas } \\
\text { therms/ } \\
\mathrm{ft}^{2} \cdot \mathrm{yr}\end{array}$ & $\begin{array}{l}\text { Electric } \\
\mathrm{kWh} / \\
\mathrm{ft}^{2} \cdot \mathrm{yr}\end{array}$ & $\begin{array}{c}\text { Gas } \\
\text { therms/ } \\
\mathrm{ft}^{2} \cdot \mathrm{yr}\end{array}$ & $\begin{array}{l}\text { Electric } \\
\mathrm{kWh} / \\
\mathrm{ft}^{2} \cdot \mathrm{yr}\end{array}$ & $\begin{array}{c}\text { Gas } \\
\text { therms/ } \\
\mathrm{ft}^{2} \cdot \mathrm{yr}\end{array}$ \\
\hline \multicolumn{13}{|l|}{ Base Code: 90.1-2007 } \\
\hline Heating, Humidification & 0.342 & 0.002 & 0.831 & 0.057 & 0.000 & 0.092 & 0.000 & 0.134 & 0.844 & 0.009 & 0.000 & 0.069 \\
\hline Cooling & 1.132 & 0.000 & 3.554 & 0.000 & 1.889 & 0.000 & 2.109 & 0.000 & 1.929 & 0.000 & 1.045 & 0.000 \\
\hline Fans, Pumps, Heat Recovery & 1.426 & 0.000 & 1.931 & 0.000 & 4.017 & 0.000 & 1.733 & 0.000 & 2.035 & 0.000 & 2.201 & 0.000 \\
\hline Lighting, Interior \& Exterior & 4.881 & 0.000 & 3.413 & 0.000 & 6.807 & 0.000 & 4.864 & 0.000 & 3.814 & 0.000 & 1.426 & 0.000 \\
\hline Plugs, Refrigeration, Other & 2.666 & 0.000 & 12.753 & 0.000 & 2.196 & 0.000 & 5.441 & 0.046 & 3.870 & 0.092 & 4.262 & 0.000 \\
\hline Service Water Heating (SWH) & 0.911 & 0.000 & 0.000 & 0.010 & 0.000 & 0.037 & 0.105 & 0.016 & 0.000 & 0.131 & 3.294 & 0.000 \\
\hline Total & 11.359 & 0.002 & 22.482 & 0.068 & 14.909 & 0.129 & 14.252 & 0.196 & 12.492 & 0.232 & 12.228 & 0.069 \\
\hline \multicolumn{13}{|l|}{ ASHRAE 90.1-2010 } \\
\hline Heating, Humidification & 0.335 & 0.002 & 1.688 & 0.037 & 0.000 & 0.116 & 0.000 & 0.056 & 0.833 & 0.011 & 0.000 & 0.055 \\
\hline Cooling & 1.016 & 0.000 & 2.045 & 0.000 & 1.423 & 0.000 & 1.569 & 0.000 & 1.646 & 0.000 & 1.064 & 0.000 \\
\hline Fans, Pumps, Heat Recovery & 1.312 & 0.000 & 1.723 & 0.000 & 2.893 & 0.000 & 1.666 & 0.000 & 1.908 & 0.000 & 2.044 & 0.000 \\
\hline Lighting, Interior \& Exterior & 3.307 & 0.000 & 2.490 & 0.000 & 5.670 & 0.000 & 3.145 & 0.000 & 2.917 & 0.000 & 1.189 & 0.000 \\
\hline Plugs, Refrigeration, Other & 2.474 & 0.000 & 12.326 & 0.000 & 2.190 & 0.000 & 5.326 & 0.046 & 3.799 & 0.092 & 4.211 & 0.000 \\
\hline Service Water Heating (SWH) & 0.910 & 0.000 & 0.000 & 0.010 & 0.000 & 0.036 & 0.097 & 0.016 & 0.000 & 0.131 & 3.294 & 0.000 \\
\hline Total & 9.355 & 0.002 & 20.273 & 0.048 & 12.176 & 0.152 & 11.803 & 0.117 & 11.104 & 0.234 & 11.801 & 0.055 \\
\hline Total Savings & 2.005 & 0.001 & 2.209 & 0.020 & 2.733 & -0.023 & 2.449 & 0.079 & 1.388 & -0.002 & 0.427 & 0.015 \\
\hline
\end{tabular}


Table 14.C. Annual Energy Usage for Buildings in the State of Utah in Climate Zone 6B

\begin{tabular}{|c|c|c|c|c|c|c|c|c|c|c|c|c|}
\hline \multirow{2}{*}{$\begin{array}{l}\text { Energy } \\
\text { End-Use }\end{array}$} & \multicolumn{2}{|c|}{ Small Office } & \multicolumn{2}{|c|}{ Large Office } & \multicolumn{2}{|c|}{ Stand-Alone Retail } & \multicolumn{2}{|c|}{ Primary School } & \multicolumn{2}{|c|}{ Small Hotel } & \multicolumn{2}{|c|}{ Mid-rise Apartment } \\
\hline & $\begin{array}{l}\text { Electric } \\
\mathrm{kWh} / \\
\mathrm{ft}^{2} \cdot \mathrm{yr}\end{array}$ & $\begin{array}{c}\text { Gas } \\
\text { therms/ } \\
\mathrm{ft}^{2} \cdot \mathrm{yr} \\
\end{array}$ & $\begin{array}{l}\text { Electric } \\
\mathrm{kWh} / \\
\mathrm{ft}^{2} \cdot \mathrm{yr}\end{array}$ & $\begin{array}{c}\text { Gas } \\
\text { therms/ } \\
\mathrm{ft}^{2} \cdot y \mathrm{r} \\
\end{array}$ & $\begin{array}{l}\text { Electric } \\
\mathrm{kWh} / \\
\mathrm{ft}^{2} \cdot \mathrm{yr}\end{array}$ & $\begin{array}{c}\text { Gas } \\
\text { therms/ } \\
\mathrm{ft}^{2} \cdot \mathrm{yr}\end{array}$ & $\begin{array}{l}\text { Electric } \\
\mathrm{kWh} / \\
\mathrm{ft}^{2} \cdot \mathrm{yr}\end{array}$ & $\begin{array}{c}\text { Gas } \\
\text { therms/ } \\
\mathrm{ft}^{2} \cdot \mathrm{yr}\end{array}$ & $\begin{array}{l}\text { Electric } \\
\mathrm{kWh} / \\
\mathrm{ft}^{2} \cdot \mathrm{yr}\end{array}$ & $\begin{array}{c}\text { Gas } \\
\text { therms/ } \\
\mathrm{ft}^{2} \cdot \mathrm{yr}\end{array}$ & $\begin{array}{l}\text { Electric } \\
\mathrm{kWh} / \\
\mathrm{ft}^{2} \cdot \mathrm{yr}\end{array}$ & $\begin{array}{c}\text { Gas } \\
\text { therms/ } \\
\mathrm{ft}^{2} \cdot \mathrm{yr} \\
\end{array}$ \\
\hline \multicolumn{13}{|l|}{ Base Code: 90.1-2007 } \\
\hline Heating, Humidification & 0.392 & 0.005 & 0.981 & 0.062 & 0.000 & 0.109 & 0.000 & 0.157 & 1.054 & 0.012 & 0.000 & 0.073 \\
\hline Cooling & 0.971 & 0.000 & 3.384 & 0.000 & 1.627 & 0.000 & 1.826 & 0.000 & 1.721 & 0.000 & 0.889 & 0.000 \\
\hline Fans, Pumps, Heat Recovery & 1.353 & 0.000 & 1.948 & 0.000 & 4.063 & 0.000 & 1.755 & 0.000 & 2.035 & 0.000 & 2.012 & 0.000 \\
\hline Lighting, Interior \& Exterior & 4.880 & 0.000 & 3.412 & 0.000 & 6.807 & 0.000 & 4.864 & 0.000 & 3.813 & 0.000 & 1.425 & 0.000 \\
\hline Plugs, Refrigeration, Other & 2.666 & 0.000 & 12.753 & 0.000 & 2.196 & 0.000 & 5.441 & 0.046 & 3.870 & 0.092 & 4.262 & 0.000 \\
\hline Service Water Heating (SWH) & 0.911 & 0.000 & 0.000 & 0.011 & 0.000 & 0.038 & 0.105 & 0.016 & 0.000 & 0.139 & 3.479 & 0.000 \\
\hline Total & 11.175 & 0.005 & 22.479 & 0.073 & 14.693 & 0.147 & 13.990 & 0.219 & 12.492 & 0.244 & 12.066 & 0.073 \\
\hline \multicolumn{13}{|l|}{ ASHRAE 90.1-2010 } \\
\hline Heating, Humidification & 0.390 & 0.004 & 1.737 & 0.048 & 0.000 & 0.131 & 0.000 & 0.066 & 1.125 & 0.015 & 0.000 & 0.065 \\
\hline Cooling & 0.863 & 0.000 & 1.764 & 0.000 & 1.103 & 0.000 & 1.295 & 0.000 & 1.444 & 0.000 & 0.906 & 0.000 \\
\hline Fans, Pumps, Heat Recovery & 1.245 & 0.000 & 1.773 & 0.000 & 2.756 & 0.000 & 1.804 & 0.000 & 1.908 & 0.000 & 1.910 & 0.000 \\
\hline Lighting, Interior \& Exterior & 3.309 & 0.000 & 2.490 & 0.000 & 5.924 & 0.000 & 3.154 & 0.000 & 2.918 & 0.000 & 1.188 & 0.000 \\
\hline Plugs, Refrigeration, Other & 2.473 & 0.000 & 12.326 & 0.000 & 2.190 & 0.000 & 5.325 & 0.046 & 3.799 & 0.092 & 4.211 & 0.000 \\
\hline Service Water Heating (SWH) & 0.910 & 0.000 & 0.000 & 0.011 & 0.000 & 0.037 & 0.097 & 0.016 & 0.000 & 0.139 & 3.478 & 0.000 \\
\hline Total & 9.189 & 0.004 & 20.090 & 0.059 & 11.973 & 0.168 & 11.675 & 0.129 & 11.194 & 0.247 & 11.693 & 0.065 \\
\hline Total Savings & 1.985 & 0.001 & 2.389 & 0.014 & 2.720 & -0.021 & 2.315 & 0.090 & 1.298 & -0.003 & 0.374 & 0.008 \\
\hline
\end{tabular}




\section{References}

(ASHRAE) ANSI/ASHRAE/IESNA - American National Standards Institute, American Society of Heating, Refrigerating and AirConditioning Engineers, and Illuminating Engineering Society of North America. 2007. ANSI/ASHRAE/IESNA 90.1-2007, Energy Standard for Buildings Except Low-Rise Residential Buildings. American Society of Heating, Refrigerating and Air-Conditioning Engineers, Atlanta, Georgia.

(ASHRAE) ANSI/ASHRAE/IES. 2010. ANSI/ASHRAE/IES 90.1-2010, Energy Standard for Buildings Except Low-Rise Residential Buildings. American Society of Heating, Refrigerating and Air-Conditioning Engineers, Atlanta, Georgia.

Bureau of Labor Statistics. 2013. "Producer Price Indexes, Table 6." Washington, D.C. Accessed March 25, 2013 at www.bls.gov/ppi/tables.htm.

Capital Funders. 2012. "Commercial Mortgage Rates, April 28, 2012, Start Rate, All." Chicago, Illinois. Accessed March 25, 2013 at www.capitalfunders.com/CommercialMortgageRates.htm.

Commercial Loan Direct. 2013. "Commercial Mortgage Interest Rates - Nationwide Lending, Mid Balance - Investor/Owner Occupied." Atlanta, Georgia. Accessed March 25, 2013 at www.commercialloandirect.com/commercial-rates.php.

(DOE) United States Department of Energy. 2012. "Residential IECC Cost Effectiveness Analysis and Results". U.S. Department of Energy, Washington, D.C. Accessed April 4, 2013 at www.energycodes.gov/development/residential/iecc analysis.

(FTA) Federation of Tax Administrators. 2013. "Range of State Corporate Income Tax Rates." Washington, D.C. Accessed March 25, 2013 at www.taxadmin.org/Fta/rate/corp inc.pdf.

Fuller, S.K., and S.R. Petersen. 1995. Life-Cycle Costing Manual for the Federal Energy Management Program, NIST Handbook 135. U.S. Department of Commerce, Washington, D.C.

Jarnagin, R.E., and G.K. Bandyopadhyay. 2010. Weighting Factors for the Commercial Building Prototypes Used in the Development of ANSI/ASHRAE/IESNA 90.1-2010. PNNL-19116, Pacific Northwest National Laboratory, Richland, Washington.

McGraw Hill Construction. 2007. McGraw Hill Construction Database (2003-2007), McGraw Hill Construction, New York, New York (available for purchase at http://dodge.construction.com/).

RS Means. 2012a. RSMeans Mechanical Cost Data, 35th Ed. Construction Publishers \& Consultants. Norwell, Massachusetts.

RS Means. 2012b. RSMeans Electrical Cost Data, 35th Ed. Construction Publishers \& Consultants. Norwell, Massachusetts.

RS Means. 2012c. RSMeans Construction Cost Data, 70th Ed. Construction Publishers \& Consultants. Norwell, Massachusetts.

RS Means. 2004. RSMeans Facilities, Maintenance and Repair Cost Data. Construction Publishers \& Consultants. Norwell, Massachusetts.

Rushing, A.S., J.D. Kneifel, B.C. Lippiatt. 2011. Energy Price Indices and Discount Factors for Life-Cycle Cost Analysis - 2011. NISTIR 853273-26, National Institute of Standards and Technology, Gaithersburg, Maryland.

Steelhead Capital. 2013. "Commercial Loan Rates, Multi-family, large portfolio, 30 years and Office / Industrial / NNN / Retail / Storage Loans, 7 year fixed, larger size." San Francisco, California. Accessed March 25, 2013 at www.steelheadcapital.com/rates.

Thornton, B.A., M.I. Rosenberg, E.E. Richman, W. Wang, Y. Xie, J. Zhang, H. Cho, V.V. Mendon and R.A. Athalye. 2011. Achieving the 30\% Goal: Energy and Cost Savings Analysis of ASHRAE Standard 90.1-2010. PNNL-20405. Pacific Northwest National Laboratory, Richland, Washington. www.energycodes.gov/sites/default/files/documents/BECP Energy Cost Savings STD2010_May2011 v00.pdf

Thornton, B.A., H. Cho, D.B. Elliot, M.A. Halverson, S.A. Loper, V.V. Mendon, M. Myer, M.I. Rosenberg, and E.E. Richman. 2013. National Cost-effectiveness of ASHRAE Standard 90.1-2010 Compared to ASHRAE Standard 90.1-2007. PNNL-22972. Pacific Northwest National Laboratory, Richland, Washington. www.energycodes.gov/sites/default/files/documents/PNNL-22972.pdf

(EIA) United States Energy Information Administration. 2012. Annual Energy Outlook 2012. DOE/EIA-0383(2012). Energy Information Administration, Washington, D.C. Accessed March 27, 2013 at www.eia.gov/forecasts/aeo/pdf/0383(2012).pdf.

(EIA) 2013. "Energy Prices by Sector and Source, United States." Energy Information Administration, Washington, D.C. Accessed April 10, 2013 at www.eia.gov/oiaf/aeo.

U.S Department of Energy

Energy Efficiency and Renewable Energy

BUILDING TECHNOLOGIES OFFICE
EERE Information Center

1-877-EERE-INFO (1-877-337-3463)

www.eere.energy.gov/informationcenter
Building Energy Codes

For information on Building Energy

Codes, visit www.energycodes.gov 